\begin{tabular}{|c|c|c|}
\hline 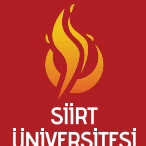 & $\begin{array}{c}\text { Türkiye Tarımsal Araştırmalar Dergisi } \\
\text { dergipark.gov.tr/tutad }\end{array}$ & $\begin{array}{l}\text { Turk J Agric Res } \\
\text { 2019, 6(1): 102-114 } \\
\text { ○ TÜTAD } \\
\text { ISSN: 2148-2306 } \\
\text { e-ISSN: 2528-858X }\end{array}$ \\
\hline Bilimin Sisuminda & Araştırma Makalesi / Research Article & $\begin{array}{l}\text { e-ISSN: } 2528-858 X \\
\text { doi: } 10.19159 / \text { tutad.517447 }\end{array}$ \\
\hline
\end{tabular}

\title{
Gökhöyük Tarım İșletmesi Arazilerinin İdaresinde Jeoistatistik ve Coğrafi Bilgi Sistemleri Tekniklerinin Kullanımı
}

\author{
Mesut BUDAK ${ }^{* *}$, Nurullah ACIR ${ }^{2}$ \\ ${ }^{1}$ Siirt Üniversitesi, Ziraat Fakültesi, Toprak Bilimi ve Bitki Besleme Bölümü, Siirt, TÜRKIYE \\ ${ }^{2}$ Ahi Evran Üniversitesi, Ziraat Fakültesi, Toprak Bilimi ve Bitki Besleme Bölümü, Kırşehir, TÜRKIYYE
}

\begin{tabular}{ll}
\hline \multicolumn{1}{c}{ Geliş Tarihi/Received: 24.01 .2019} & Kabul Tarihi/Accepted: 26.02 .2019 \\
\hline ORCID ID (Yazar sirasina göre/ by author order) \\
\hline (D) orcid.org/0000-0001-5715-1246 (D) orcid.org/0000-0001-7591-0496 \\
${ }^{*}$ Sorumlu Yazar/Corresponding Author: m.budak@siirt.edu.tr
\end{tabular}

Öz: Arazi kullanımı, ana materyal ve topoğrafyaya bağlı olarak büyük değişkenlik gösteren toprak özelliklerinin mesafeye bağlı değişkenlikleri; toprağın verimliliği, kalitesi ve genel olarak sürdürülebilirliğini önemli düzeyde etkilemektedir. Bu çalışma; yaklaşı 1900 hektar genişliğindeki Gökhöyük Tarım İ̧̧letmesi arazilerinin bir kısım toprak özelliklerinin mesafeye bağlı değişkenliklerini belirlemek, haritalamak ve ișletme arazilerinin sürdürülebilir kullanımlarını etkileyecek sorunların tespit edilerek çözüm önerilerini ortaya koymak amacı ile gerçekleştirilmiştir. Bu amaçla, çalışma alanını temsil edecek şekilde 63 noktadan ve 4 farklı derinlikten (0-30, 30-60, 60-90 ve 90-120 cm) toprak ve 19 noktadan da taban suyu örnekleri alınmıştır. Toprak örneklerinde elektriksel iletkenlik (EC), pH, kil, kum ve silt içerikleri ile hidrolik iletkenlik değerleri; taban suyu örneklerinde ise $\mathrm{pH}$ ve EC değerleri belirlenmiştir. Klasik istatistik ve jeoistatistik yöntemler ile çalışılan özelliklerin, arazideki genel durumu ve mesafeye bağlı değişkenlikleri karakterize edilmiştir. Araştırma sonucuna göre, yüksek kil içeriğine sahip olan hem yüzey hem de yüzey altı topraklarında hidrolik iletkenlik değerleri $\left(<20 \mathrm{~mm} \mathrm{~h}^{-1}\right)$ oldukça düşük bulunmuştur. Bitki besin elementi alımı üzerine önemli bir etkisi olan pH değerlerinin tüm derinliklerde ve arazinin önemli bir kısmında 8.5'in üzerinde; çalışma alanının orta kısmında bir hatta yer alan toprakların 60-120 cm derinliğinde EC değerleri $\left(>4 \mathrm{dS} \mathrm{m}^{-1}\right)$ sorun oluşturabilecek düzeylerde olduğu tespit edilmiștir. Bu bölgedeki su örneklerinin de EC değerleri $20 \mathrm{dS} \mathrm{m}^{-1}$ 'nin üzerinde olduğu görülmüştür. Kurak ve sıcak dönemlerde tuz içeriği yüksek taban suyunun kapilarite ile yüzeye taşınması, toprağın üretkenlik fonksiyonuna zarar verebilir. Toprak özelliklerinin mesafeye bağlı değișimini gösteren haritaların kullanımı ile çiftlik arazisinde bitkisel üretimin geliştirilmesine ve toprak kalitesinin iyileştirilmesine katkı sağlayacak kararların doğru bir şekilde alınması mümkün olabilecektir.

Anahtar Kelimeler: Mesafeye bağlı değişkenlik, tuzluluk, hidrolik iletkenlik, amenajman bölgesi, jeoistatistik

\section{Use of Geostatistics and Geographical Information Systems Techniques in the Management of Gökhöyük Agricultural Farm}

\footnotetext{
Abstract: Spatial variability of soil properties which vary greatly depending on land use, parent material and topography significantly affects soil fertility, quality, and overall sustainability. This study was carried out to determine and map the spatial variability of some of soil properties in Gökhöyük Agricultural Farm, which is approximately 1900 ha, and to identify the problems that may affect the sustainable use of the land and to propose solutions. For this purpose, soil samples representing the study area were collected from 63 points and 4 different depths $(0-30,30-60,60-90$ and $90-120)$ along with 19 water samples from 1.5-2.0 m depths. Electrical conductivity (EC), pH, clay, sand, silt contents and hydraulic conductivity values of soil samples, and $\mathrm{pH}$ and $\mathrm{EC}$ values of the groundwater samples were determined from 19 points. The general status and spatial variability of soil properties studied were characterized by classical statistics and geostatistical methods. According to the results of the study, the hydraulic conductivity values $\left(<20 \mathrm{~mm} \mathrm{~h}^{-1}\right)$ were found to be very low in both surface and subsoil soils having high clay content. The $\mathrm{pH}$ values, which have a significant effect on plant nutrient availability, were higher than 8.5 at all depths in a significant portion of the study area. The EC values of soils $(60-120 \mathrm{~cm}$ depth) located in the middle part of the study area were high $\left(>4 \mathrm{dS} \mathrm{m}^{-1}\right)$, to be considered as problematic. The EC values of water samples in this location
} 
were above $20 \mathrm{dS} \mathrm{m}^{-1}$. Highly saline ground water that transported to the soil surface with capillarity in the dry and hot seasons can harm the productivity function of soils. Spatial distribution maps of the soil properties will enable to make the accurate decisions which will contribute to the development of plant production and improvement of soil quality in the farm land.

Keywords: Spatial variability, salinity, hydraulic conductivity, management zone, geostatistics

\section{Giris}

Son y1llarda artan ülke nüfusunun gereksinimlerini karşılamakta zorlanan tarımsal üretimin iyileştirilmesi ve arttırılması, üretim yeri olan toprağın fonksiyon gösterme yeteneğinin korunması ve geliştirilmesi ile mümkün olabilir. Ülkenin tarımsal üretim için uygun olan arazilerinin potansiyellerinin altında kullanılmasına neden olan sorunların teşhisi ve gerekli tedbirlerin alınarak sorunların giderilmesi öncelikli hedefler arasında olmalıdır. Doğal veya insan etkisi ile toprağın fonksiyonlarını yerine getirmesine engel olan tuzluluk, sodiklik, ağır metal kirliliği, erozyon gibi sorunların düzeltilmeleri üretimin sürdürülebilirliği için son derece gerekli olmasına karşın oldukça pahalıdır. Toprak ıslahı için yapılan çalışmalarda kullanılan materyallerin (su, 1slah maddesi vb.) miktarı, genel olarak girdilerin arazideki mesafeye bağlı değişimleri dikkate alınmadan arazinin ortalama değerine dayanarak hesaplanmış ve uygulamalar yapılmıștır (Samra ve Singh, 1990). Russo (1984), elektriksel iletkenliğin (EC) mesafeye bağlı değişkenliğini dikkate alarak uyguladığı yıkama çalışmasında, tuzlu toprakların 1slahında y1kama gereksiniminden \% 38 tasarruf edildiğini belirtmiştir. Benzer bir çalışmada Samra ve Singh (1990), arazide yapılan ölçümlerin ortalamasına göre yapılan ve toprak sodikliğinin mesafeye bağlı değişkenliğini dikkate almadan sslah malzemelerinin araziye tekdüze uygulanmasının, ıslah çalışmalarından 12 yıl sonra dahi arazide verimin ve toprak özelliklerinin düzensiz dağılımına neden olduğunu belirtmişler ve arazinin belirli bölgelerinde toprak $\mathrm{pH}$ 's1 ve sodyum (Na) konsantrasyonunun bitki gelişimini olumsuz etkileyecek düzeyde olduğunu vurgulamışlardır. Ayrıca birçok çalışmada toprak sslah maddelerinin arazinin tamaminda aynı miktarda uygulanmasının ortalamanın altındaki sodik olan yerler için fazlalık, ortalamanın üzerindeki yerler için ise yetersiz anlamına geldiği rapor edilmiştir (Sürücü ve ark., 2013; Günal ve ark., 2015).

Tuzluluk ve sodiklik sorununun idaresinde en uygun amenajman stratejilerinin geliștirilebilmesi için yüzey ve yüzey altındaki toprak katmanlarının tuzluluk/sodiklik durumunun belirlenmesine ve alansal dağılımını gösteren haritaların hazırlanmasına gereksinim duyulmaktadır (Gao ve ark., 2014). Bir alanda tuzluluğun ve alkaliliğin idaresinde yapılacak ilk iş eldeki verilerin kullanımı ile tehdit ve risk altında bulunan alanların sınırlarının doğru bir şekilde tespit edilmesidir (Eckelmann ve ark., 2006). Bu alanların tespitinin ardından, arazideki idaresinde izlenecek 3 yöntem bulunmaktadır. Bunlardan ilki, bitkinin gereksiniminden daha fazla su uygulayarak tuzların kök bölgesinin altına taşınmasıdır. İkinci durumda, drenaj kanallarının açılarak toprağın nem durumuna uygun bir şekilde yıkama fraksiyonunun uygulanması işlemidir. Üçüncü durum ise, tuzun kök bölgesinden daha uzakta zararsız olacakları bir katmana kadar uzaklaştırılması işlemidir (Bloem ve ark., 2007). Her üç durumda da tuzun kök bölgesinde zararsız seviyeye düşürülmesi için bitki gereksiniminden daha yüksek miktarda suyun uygulanması gerekmektedir. Ancak uygulanacak su ve topraktan uzaklaştırılmak istenen tuzun miktarı, toprağın tekstürü, hidrolik iletkenliği gibi çeşitli faktörlere bağlı olarak değişkenlik göstermektedir (Richards ve ark., 1954). Y1kama suyunun gereğinden fazla hesaplanmas1, daha fazla sulama suyunun uygulanmasina ve drenaj sistemindeki tuz yükünün artmasına yol açacaktır. $\mathrm{Bu}$ durum ise çevreye olumsuz etki edecek ve su kaynaklarının kullanımını sınırlandıracaktır (Corwin ve ark., 2007).

$\mathrm{Bu}$ nedenle sorunlu alanlarda etkin bir 1slah çalışması yürütmek ve girdi maliyetini düşürmek için ilgili toprak özelliklerinin mesafeye bağlı değişiminin belirlenip haritalanması gerekmektedir. Toprağın fiziksel ve kimyasal özelliklerine ait mesafeye bağlı değişimin belirlenmesinde jeoistatistiksel yöntemler yaygın bir şekilde kullanılmaktadır (Webster ve Oliver, 2001; Budak ve Günal, 2015; Dengiz ve ark., 2015; Özyazıcı ve ark., 2015, 2016, 2017). Jeoistatistikte toprak özelliklerinin mesafeye bağlı değişkenlik deseninin belirlenmesinde semivariogram, örneklenmeyen noktaların tahmininde ise krigleme yöntemi kullanılmaktadır (Kalivas ve ark., 2002). Tarımsal arazilerin idaresinde ve sürdürülebilirliğinin sağlanmasında oldukça önem arz eden dağılım haritalarımın hazırlanmasında ise Coğrafi Bilgi Sitemleri (CBS) kullanılmaktadır. Hem jeoistatistik hem de CBS teknikleri kullanılarak hazırlanan toprak özelliklerine ait değişimin haritaları ıslah uygulamalarının etkinliğini arttırmaktadır (Budak ve Günal, 2015). 
Bu çalışmanın amacı; yüksek taban suyu nedeni ile tuzluluk/sodiklik potansiyeli yüksek toprakların yer aldığ 1 ve sulama ile tarımsal üretimin yapıldığ 1 Geldigen Ovası'nda yer alan Gökhöyük Tarım İşletmesi arazilerinin ıslah ve arazi planlamalarının etkinliğin arttırılmasını sağlayacak bazı toprak özelliğinin mesafeye bağlı değişkenliklerini tanımlamak ve alansal dağılım haritalarını hazırlamaktır.

\section{Materyal ve Yöntem}

\section{1. Çalışma alanının bazı coğrafik özellikleri}

Çalışma, Amasya ili sınırları içerisindeki Geldigen Ovası'nda yer alan Gökhöyük Tarım İșletmesi Müdürlüğü ( $35^{\circ} 36^{\prime}$ 50"-35 42' 36" doğu ve $40^{\circ} 31^{\prime} 48^{\prime \prime}-40^{\circ} 35^{\prime} 15^{\prime \prime}$ kuzey) arazilerinde yürütülmüştür. Karadeniz iklimi ile karasal iklim arasında bir geçiş iklimine sahip çalışma alanında elde edilen uzun y1llara göre (1961-2014) yıllık toplam yağış miktarı $460 \mathrm{~mm}$, ortalama sıcaklık $13.5{ }^{\circ} \mathrm{C}$ ve yıllık evapotrasprasyon $1079 \mathrm{~mm}$ 'dir. Çalışma alanı nem rejimi Ustic ve sıcaklık rejimi ise Mesic'dir (Anonymous, 1999).
Alüvyal ve kolüvyal ana materyal üzerinde oluşan ve yaklaşık 1900 hektarlık alandan oluşan çalışma alanını temsil edecek şekilde 63 noktadan ve 4 farkl1 derinlikten $(0-30,30-60,60-90$ ve 90 $120 \mathrm{~cm}$ ) toprak örnekleri alınmıştır (Şekil 1). Karaca (2008) tarafindan yapilan sinıflandırmaya göre çalışma alanı toprakları Entisol ve İnceptisol ordolarından oluşmaktadır.

\subsection{Toprak analiz yöntemleri}

Çalıșma alanına ait toprakların bazı fiziksel ve kimyasal özelliklerinin belirlenmesi amacı ile alınan bozulmuş toprak örnekleri laboratuvar şartlarında kurutulup, 2 mm'lik elekten geçirilmiş ve analize hazır hale getirilmiştir. Çalışmada, parçacık büyüklük dağılımı (kil, silt ve kum içeriği), hidrometre yöntemine göre (Gee ve Bauder, 1986); elektriksel iletkenlik (EC) ve toprak reaksiyonu $(\mathrm{pH}), 1: 2.5$ saf su çözeltisinde $\mathrm{pH} / \mathrm{EC}$ metreyle ölçülmüştür (Rhoades ve Chanduvi, 1999). Doymuş hidrolik iletkenlik ise Saxton ve ark. (1986) yöntemine göre toprak tekstürü bileşenlerinden tahmin edilerek belirlenmiştir.

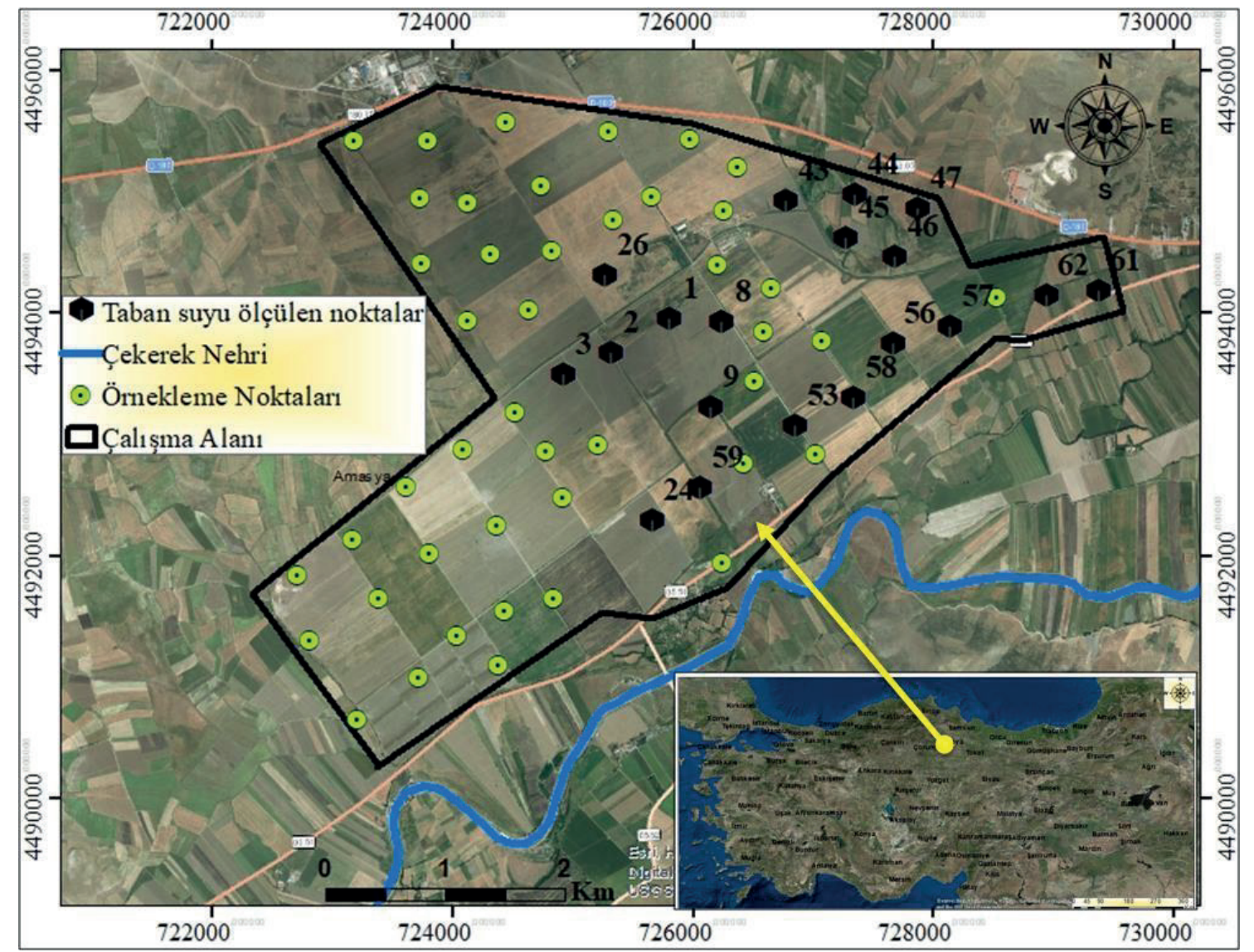

Şekil 1. Çalışma alanının konumu ve örnekleme deseni 
2.3. Mesafeye bağlı değişkenliğin analizi ve haritaların hazırlanması

Fiziksel ve kimyasal toprak özelliklerine ait mesafeye bağlı değişkenliğin analizinde ve haritalanmasında jeoistatistiksel teknikler kullanılmıştır (Goovaerts, 1999; Mulla ve McBratney, 2000). Toprak özelliklerinin mesafeye bağlı değişkenlikleri analiz edilmeden önce, normal dağılım gösterip göstermedikleri kontrol edilmiştir. Normal dağılım göstermeyen toprak özelliklerine ait verilere logaritmik dönüşüm uygulanmış ve daha sonra jeoistatistiksel yöntemler ile modellenmiştir. Semivariogramlar oluşturulurken mesafeye bağl1 değişkenliği en iyi tanımlayan modelin seçiminde modele ait $r^{2}$ ve ölçüm hatalarının göstergesi olan Artık Kareler Toplamı (RSS) değerleri dikkate alınmıştır. En iyi modelin seçiminde $r^{2}$ değerinin 1.0 'e ve RSS değerinin ise sıfır (0)'a yakın olanları tercih edilmiştir (Yang ve ark., 2011). Semivariogram ve çapraz değerlendirme sonucu elde edilen parametreler kullanılarak ArcGIS 10.2.1 paket programının jeoistatistik modülünde yer alan
Ordinary Kriging yöntemi ile toprak özelliklerine ait mesafeye bağlı değişim haritaları hazırlanmıştır.

\section{Bulgular ve Tartışma}

Çalışma alanında 4 farklı derinlikten alınan toprak örneklerinin bazı fiziksel ve kimyasal özeliklerine ait tanımlayıcı istatistik parametreleri Tablo 1'de verilmiştir. Çalışma alanı sınırları içerisinde 19 noktada bulunan taban suyu gözlem kuyularından alınan su örneklerine ait $\mathrm{pH}$ ve EC değerleri ise Tablo 2'de verilmiştir.

\section{1. Çalıșma alanı topraklarının bazı fiziksel ve kimyasal özellikleri}

Kurak ve yarı-kurak iklimlerde yer alan ve sulama ile yapılan tarımsal üretimin sürdürülebilirliğini tehdit eden en önemli engellerden biri olan tuzluğun tanımlanmasında kullanılan en yaygın kriter toprağın EC değeridir. Toprak tekstürünün derinlikle beraber çok değişmediği çalışma alanında EC değerlerinin önemli miktarda artış gösterdiği görülmüștür

Tablo 1. Toprak bazı özelliklerine ait tanımlayıcı istatistik verileri $(n=63)$

\begin{tabular}{|c|c|c|c|c|c|c|c|c|}
\hline Toprak özelliği & Derinlik $(\mathrm{cm})$ & En küçük & En büyük & Ortalama & Standart sapma & $\% \mathrm{VK}$ & Çarpıklık & Basıklık \\
\hline \multirow{4}{*}{ Kil (\%) } & $0-30$ & 19.50 & 69.50 & 50.81 & 11.17 & 21.99 & -0.86 & 0.63 \\
\hline & $30-60$ & 12.00 & 72.00 & 48.31 & 13.49 & 27.92 & -0.90 & 0.57 \\
\hline & $60-90$ & 20.75 & 70.75 & 47.16 & 13.23 & 28.06 & -0.36 & -0.70 \\
\hline & $90-120$ & 20.75 & 69.50 & 44.52 & 13.84 & 31.09 & 0.08 & -1.06 \\
\hline \multirow{4}{*}{ Kum (\%) } & $0-30$ & 13.00 & 53.00 & 23.32 & 7.73 & 33.16 & 1.15 & 2.28 \\
\hline & $30-60$ & 11.75 & 70.50 & 25.42 & 12.14 & 47.77 & 1.90 & 4.29 \\
\hline & $60-90$ & 11.75 & 60.50 & 27.37 & 11.37 & 41.54 & 1.04 & 0.96 \\
\hline & $90-120$ & 10.50 & 68.00 & 28.21 & 12.42 & 44.04 & 1.22 & 1.35 \\
\hline \multirow{4}{*}{ Silt (\%) } & $0-30$ & 12.50 & 52.50 & 25.87 & 7.82 & 30.24 & 1.17 & 1.52 \\
\hline & $30-60$ & 13.75 & 63.75 & 26.27 & 10,28 & 39.13 & 1.71 & 3.20 \\
\hline & $60-90$ & 5.00 & 48.75 & 25.48 & 8.89 & 34.90 & 0.58 & 0.60 \\
\hline & $90-120$ & 6.25 & 61.25 & 27.27 & 11.17 & 40.97 & 0.88 & 0.47 \\
\hline \multirow{4}{*}{$\mathrm{pH}$} & $0-30$ & 8.00 & 9.70 & 8.39 & 0.32 & 3.83 & 2.48 & 7.73 \\
\hline & $30-60$ & 8.02 & 9.75 & 8.50 & 0.30 & 3.53 & 2.25 & 7.05 \\
\hline & $60-90$ & 8.10 & 9.56 & 8.64 & 0.34 & 3.92 & 1.18 & 0.96 \\
\hline & $90-120$ & 8.05 & 9.47 & 8.62 & 0.34 & 3.90 & 0.66 & -0.11 \\
\hline \multirow{4}{*}{$\mathrm{EC}\left(\mathrm{dS} \mathrm{m}^{-1}\right)$} & $0-30$ & 0.22 & 1.96 & 0.53 & 0.37 & 70.63 & 2.74 & 7.15 \\
\hline & $30-60$ & 0.27 & 2.83 & 0.58 & 0.45 & 76.76 & 3.05 & 10.97 \\
\hline & $60-90$ & 0.16 & 4.82 & 0.90 & 0.94 & 104.00 & 2.37 & 5.71 \\
\hline & $90-120$ & 0.20 & 4.67 & 1.30 & 1.09 & 83.54 & 1.28 & 0.90 \\
\hline \multirow{4}{*}{$\begin{array}{l}\text { Hidrolik } \\
\text { iletkenlik } \\
\left(\mathrm{cm} \mathrm{h}^{-1}\right)\end{array}$} & $0-30$ & 0.13 & 0.86 & 0.23 & 0.13 & 55.19 & 3.85 & 16.44 \\
\hline & $30-60$ & 0.15 & 2.03 & 0.30 & 0.33 & 110.25 & 3.71 & 14.79 \\
\hline & $60-90$ & 0.13 & 0.82 & 0.25 & 0.15 & 60.43 & 2.41 & 5.44 \\
\hline & $90-120$ & 0.15 & 0.99 & 0.28 & 0.17 & 60.68 & 2.26 & 5.34 \\
\hline
\end{tabular}

VK: Varyasyon katsayıs1

(Tablo 1). Yağış veya sulama suları ile birlikte toprak profilinin üst katmanında bulunan tuzlar alt katmanlara doğru yıkanmakta ve toprak profilinden uzaklaşmaktadır (Blaylock, 1994).

Çalışma alanında drenajın yetersiz olmasının yanı sıra, bölgedeki yağışın buharlaşmadan önemli düzeyde az olması tuzların yıkanıp toprak profilinden uzaklaşmasını engellemektedir. Çalışma alanında ilk $60 \mathrm{~cm}$ toprak derinliğinde EC değerleri genel olarak bitkisel üretim açısından sorun $\left(>4 \mathrm{dS} \mathrm{m}^{-1}\right)$ oluşturmamakla beraber yer yer $2.82 \mathrm{dS} \mathrm{m}^{-1}$ 'e kadar çıkmıştır. Ancak 60-120 cm 
derinlikte EC değerleri artış göstermiş ve $4.67 \mathrm{dS}$ $\mathrm{m}^{-1}$ 'e kadar çıkmış ve bitkisel üretim için sınır değerleri aşmıştır (Tablo 1).

Tablo 2. Çalışma alanı içerisinde yer alan taban suyu gözlem kuyularına ait veriler

\begin{tabular}{ccc}
\hline Taban suyu no & $\mathrm{pH}$ & $\mathrm{EC}\left(\mathrm{dS} \mathrm{m}^{-1}\right)$ \\
\hline 1 & 7.51 & 21.80 \\
2 & 7.44 & 24.70 \\
3 & 7.46 & 8.76 \\
8 & 7.52 & 11.15 \\
9 & 7.19 & 9.12 \\
24 & 7.42 & 3.03 \\
26 & 7.48 & 1.65 \\
43 & 7.60 & 1.53 \\
44 & 7.54 & 2.28 \\
45 & 8.07 & 11.39 \\
46 & 7.99 & 11.37 \\
47 & 8.23 & 11.16 \\
53 & 7.67 & 2.83 \\
56 & 7.69 & 3.13 \\
57 & 7.87 & 2.64 \\
58 & 7.59 & 1.29 \\
59 & 7.50 & 4.91 \\
61 & 7.47 & 9.40 \\
62 & 7.72 & 4.38 \\
\hline
\end{tabular}

Kurak ve yarı-kurak alanlarda toprak tuzluluğu, sulama suyunda yer alan çözünmüş tuzların taşınması veya antik deniz birikintileri ya da önceki playa (eski çökelti alanı) alanları nedeniyle toprakta mevcut tuz seviyesinin yüksek olmasından kaynaklanabilmektedir. Zayıf drenaj ve yüksek tuz konsantrasyonuna sahip yüzlek su tablası bu tuzların kök bölgesine ve potansiyel olarak yüzeye taşınmasına yol açarak bu sorunu daha da kötüleştirmektedir (Horney ve ark., 2005). Tablo 2 incelendiğinde su örneklerinin alındığı noktalarda ortalama seviyesi $1.5 \mathrm{~m}$ derinlikte olan taban suyunun önemli düzeyde tuz içerdiği görülmektedir. Tuz konsantrasyonu 1.29 ile 24.70 $\mathrm{dS} \mathrm{m} \mathrm{m}^{-1}$ arasında değişim göstermiştir. Tuz içeriği yüksek olan taban sularının buharlaşmanın yüksek olduğu aylarda profilin üst kısımlarına kadar kapilarite yoluyla taşındı ğ 1 ve özellikle $60-120 \mathrm{~cm}$ derinlikte önemli miktarda tuz birikimine neden olduğu anlaşılmaktadır (Tablo 2).

Arazi içerisinde herhangi bir özelliğin değişkenliğinin boyutunun belirlenmesinde varyasyon katsayısı (VK) değerleri yaygın bir şekilde kullanılmaktadır. Varyasyon katsayısının \% 15'ten küçük olması durumunda az değişken, $\% 15$ ile \% 35 arasında olması durumunda orta değişken ve \% 35'ten büyük olmasında ise çok değişken olarak değerlendirilmektedir (Wilding, 1985). Çalışma alanı toprakları kumludan ağır killiye değin değişkenlik göstermektedir. Yüzey topraklarında \% 69.5 kil içeren yerler olduğu gibi \% 53 kum içeren lokasyonlar da bulunmaktadır
(Tablo 1). Çekerek Nehri'nin hemen kıyısında bulunan çalışma alanında toprakların tekstürleri üzerine nehrin depolama rejimi önemli düzeyde etkili olmuştur. Örnekleme yapılan derinliklerin hepsinde kil içeriğinin hesaplanan VK değeri orta düzeyde değişkenliğin olduğunu göstermektedir. Kum içeriği yüzeyde orta düzeyde değişkenlik (\% 33.16) gösterirken, yüzey altı topraklarında yüksek düzeyde değişkendir ( $>\%$ 35). Belirlenen özellikler içerisinde en düşük VK değerinin dört derinlikte de $\mathrm{pH}$ değerlerinde olduğu görülmektedir. Tüm arazide oldukça homojen görünen $\mathrm{pH}$ değerleri ortalama $8.39(0-30 \mathrm{~cm})$ ile $8.64(60-90 \mathrm{~cm})$ arasında değişmiştir. Bununla birlikte pH'nın yer yer $9.75(30-60 \mathrm{~cm})$ gibi yüksek değerlere çıktığ 1 da olmuştur. $\mathrm{pH}$ değerlerinin bu denli yüksek olması, kök bölgesindeki başta fosfor olmak üzere birçok besin elementinin bitkiye yarayışlılığını olumsuz etkilemesi söz konusudur. Toprağın hidrolik iletkenliği ile birlikte en değişken olan bir diğer toprak özelliği de EC'dir. Hesaplanan VK değerleri tüm katmanlarda hidrolik iletkenlik ve EC'nin arazide oldukça büyük değişkenlik gösterdiğine işaret etmektedir.

\section{2. Çalışma alanı topraklarının mesafeye bağlı değişkenlikleri}

Jeostatistiksel analizler çalışılan 5 toprak özelliğine ait 4 farklı derinliğin mesafeye bağlı dağılımlarının modellenmesinde çoğunlukla küresel modellerin kullanılabileceğini göstermiştir. Toprak özeliklerinin farklı derinlikleri için elde edilen modellere ait parametreler ve hesaplanan uzaysal bağımlılık seviyeleri Tablo 3-5'te verilmiştir. Toprak biliminde jeoistatistiğin en temel uygulaması örnekleme yapılmayan alanlarda toprak özelliklerinin değerlerinin tahmin edilmesi ve haritalanmasıdır. Tahmin için oluşturulan modellerin kullanımı ile oluşturulan alansal dağılım haritaları Şekil 2-4'te gösterilmektedir.

\subsubsection{Kil ve kum içeriğinin derinlikle ve mesafeye bağlı olarak değişimi}

Toprakların kil ve kum içerikleri, toprağın kimyasal ve hidrolojik özelliklerini etkileyen en önemli bileşenlerdir. Arazide toprakların kil ve kum kapsamlarındaki değişimler; su tutma kapasitesine, suyun yarayışlılığına, suyun hareketine dolayısı ile tuzların yıkanma derecesine önemli düzeyde etki etmektedir. Tuzlu ve alkali toprakların 1slahında kullanılacak su miktarının belirlenmesi toprağın kil ve kum içeriği ile yakından ilişkilidir. Toprakların kil ve kum içerikleri hem arazi boyunca hem de derinlikle beraber önemli değişkenlikler gösterebilmektedir. $\mathrm{Bu}$ nedenle etkin bir 1slah çalışmasının yürütülmesi için toprakların kil ve kum içeriklerine ait spatial değişkenliğinin dikkate 
alınması gerekmektedir. Özellikle de kurak bölgelerde hidrolojik döngüdeki fonksiyonundan dolayı yüzey altı toprakların kil içeriği oldukça önem arz etmektedir. Toprakta kil içeriğinin yüksek olması suyun hareketini yavaşlatmakta, derine drenajını engellemekte ve potansiyel olarak suyun profil içerisinde göllenmesine neden olmaktadır
(Triantafilis ve Lesch, 2005). Farklı derinliklerden alınan kil ve kum içeriklerine ait modellere ait parametreler Tablo 3'te verilmiştir. Elde edilen modeller incelendiğinde hem kil içeriği hem de kum içeriği için tüm derinliklerde en iyi modelin küresel model olduğu tespit edilmiştir (Tablo 3).

Tablo 3. Kil ve kum için elde edilen semivariogram modellerine ait parametreler

\begin{tabular}{lccccccccc}
\hline $\begin{array}{l}\text { Toprak } \\
\text { özelliği }\end{array}$ & Derinlik & Model & $\begin{array}{c}\text { Nugget } \\
(\mathrm{Co})\end{array}$ & $\begin{array}{c}\text { Sill } \\
(\mathrm{Co}+\mathrm{C})\end{array}$ & $\begin{array}{c}\text { Uzaysal } \\
\text { bağıllılık }\end{array}$ & $\begin{array}{c}\text { Range } \\
(\mathrm{m})\end{array}$ & $\mathrm{r}^{2}$ & RSS & $\begin{array}{c}\text { Dağllim } \\
\text { ön işlemi }\end{array}$ \\
\hline \multirow{4}{*}{ Kil } & $0-30$ & Küresel & 0.1 & 140.70 & 0.07 & 1737 & 0.99 & 94.8 & Normal \\
& $30-60$ & Küresel & 77.6 & 210.0 & 36.95 & 1374 & 0.92 & 607.00 & Normal \\
& $60-90$ & Küresel & 0.1 & 182.20 & 0.05 & 893 & 0.71 & $6.59 \mathrm{E}+03$ & Normal \\
& $90-120$ & Küresel & 92.3 & 216.10 & 42.71 & 1565 & 0.94 & $4.52 \mathrm{E}+02$ & Normal \\
\hline \multirow{4}{*}{ Kum } & $0-30$ & Küresel & 0.054 & 0.12 & 45.00 & 4300 & 0.93 & $3.60 \mathrm{E}-04$ & Log. dönüşüm \\
& $30-60$ & Küresel & 0.0001 & 0.179 & 0.06 & 774 & 0.89 & $1.14 \mathrm{E}-03$ & Log. dönüşüm \\
& $60-90$ & Küresel & 0.1 & 118.80 & 0.08 & 751 & 0.8 & $7.34 \mathrm{E}+02$ & Normal \\
& $90-120$ & Küresel & 0.0001 & 0.176 & 0.06 & 1009 & 0.83 & $6.81 \mathrm{E}-03$ & Log. dönüşüm \\
\hline
\end{tabular}

Tablo 4. pH ve EC için elde edilen semivariogram modellerine ait parametreler

\begin{tabular}{|c|c|c|c|c|c|c|c|c|c|}
\hline $\begin{array}{l}\text { Toprak } \\
\text { özelliği }\end{array}$ & Derinlik & Model & $\begin{array}{c}\text { Nugget } \\
(\mathrm{Co})\end{array}$ & $\begin{array}{c}\text { Sill } \\
(\mathrm{Co}+\mathrm{C})\end{array}$ & $\begin{array}{c}\text { Uzaysal } \\
\text { bağımlılık }\end{array}$ & Range & $r^{2}$ & RSS & $\begin{array}{l}\text { Dağılım } \\
\text { ön işlemi }\end{array}$ \\
\hline \multirow{4}{*}{$\mathrm{pH}$} & $0-30$ & Küresel & 0.000003 & 0.00013 & 2.31 & 1156 & 0.83 & 7.92E-08 & Log. dönüşüm \\
\hline & $30-60$ & Küresel & 0.00001 & 0.00086 & 1.16 & 981 & 0.74 & $1.56 \mathrm{E}-03$ & Log. dönüşüm \\
\hline & $60-90$ & Küresel & 0.0001 & 0.106 & 0.09 & 889 & 0.75 & $3.10 \mathrm{E}-03$ & Normal \\
\hline & $90-120$ & Küresel & 0.00001 & 0.119 & 0.01 & 902 & 0.92 & 8.07E-07 & Normal \\
\hline \multirow{4}{*}{$\mathrm{EC}$} & $0-30$ & Küresel & 0.0011 & 0.222 & 0.50 & 1009 & 0.73 & $2.37 \mathrm{E}-03$ & Log. dönüşüm \\
\hline & $30-60$ & Küresel & 0.0406 & 0.336 & 12.08 & 1435 & 0.9 & $3.22 \mathrm{E}-03$ & Log. dönüşüm \\
\hline & $60-90$ & Küresel & 0.001 & 0.584 & 0.17 & 908 & 0.63 & $8.40 \mathrm{E}-02$ & Log. dönüşüm \\
\hline & $90-120$ & Üssel & 0.0193 & 0.246 & 7.86 & 1380 & 0.93 & $4.22 \mathrm{E}-04$ & Log. dönüşüm \\
\hline
\end{tabular}

Tablo 5. Hidrolik iletkenlik için elde edilen semivariogram modellerine ait parametreler

\begin{tabular}{|c|c|c|c|c|c|c|c|c|c|}
\hline $\begin{array}{l}\text { Toprak } \\
\text { özelliği }\end{array}$ & Derinlik & Model & $\begin{array}{c}\text { Nugget } \\
\text { (Co) }\end{array}$ & $\begin{array}{c}\text { Sill } \\
(\mathrm{Co}+\mathrm{C})\end{array}$ & $\begin{array}{c}\text { Uzaysal } \\
\text { bağımlılık }\end{array}$ & Range & $r^{2}$ & RSS & $\begin{array}{l}\text { Dağılım } \\
\text { ön islemi }\end{array}$ \\
\hline \multirow{4}{*}{$\begin{array}{l}\text { Hidrolik } \\
\text { iletkenlik }\end{array}$} & $0-30$ & Küresel & 0.0209 & 0.1498 & 13.95 & 1906 & 0.97 & 2.99E-04 & Log. dönüssüm \\
\hline & $30-60$ & Küresel & 0.079 & 0.4470 & 17.67 & 1837 & 0.99 & 2.59E-05 & Log. dönüşüm \\
\hline & $60-90$ & Üssel & 0.0204 & 0.2078 & 9.82 & 993 & 0.91 & 4.87E-04 & Log. dönüşüm \\
\hline & $90-120$ & Küresel & 0.001 & 0.2130 & 0.47 & 1191 & 0.91 & $3.70 \mathrm{E}-02$ & Log. dönüşüm \\
\hline
\end{tabular}

Nugget semivaryansin toplam semivaryansa oranının $(\mathrm{Co} / \mathrm{Co}+\mathrm{C})$ yüzde olarak ifadesi uzaysal bağımlılık olarak tanımlanmıştır. Uzaysal bağımlılık değeri $\leq \% 25$ olduğunda incelenen özellik kuvvetli uzaysal bağımlı, \% 25 ile \% 75 arasında ise orta derecede uzaysal bağımlı ve bu oran \% 75'ten fazla ise değişken zayıf uzaysal bağımlı olarak sınıflandırılmaktadır (Cambardella ve ark., 1994). Bu değerlendirmeye göre 0-30 ve 60-90 cm derinliklerde kuvvetli uzaysal bağımlılığa sahip olan kil içeriğinin 30-60 ve 90-120 cm derinliklerde orta derecede uzaysal bağımlığa sahip olduğu anlaşılmaktadır. Arazideki kum içeriği ise yüzeyde orta derecede uzaysal bağımlılığa sahip iken diğer 3 derinlikte kuvvetli uzaysal bağımlılığa sahip olduğu görülmektedir (Tablo 3). Toprak özelliklerinin uzaysal bağımlılıkları genetik (ana materyal ve topoğrafya gibi toprak oluşum faktörleri) veya amenajmana bağlı (gübreleme ve toprak işleme gibi kullanım ile ilişkili) olarak değişkenlik göstermektedir. Genellikle kuvvetli uzaysal bağımlılığa sahip olan toprak özelliklerinin uzaysal bağımlılığı genetik faktörler ile ve zayıf uzaysal bağımlılığa sahip olanların uzaysal bağımlılığ (Cambardella ve ark., 1994). Çalışma alanı toprakları, kuzeyindeki yüksek arazilerden gelen kireç taşı kökenli koluviyal malzeme ve güzeyindeki Çekerek Nehri'nin depozitleri üzerinde oluşmuştur. Bu iki ayrı kaynaktan gelen malzemelerin etkisi ile tekstür bileşenlerinin kuvvetli uzaysal bağımlılığa sahip oldukları düşünülmektedir.

Mesafeye bağlı değişkenlik analizinde belirlenen range (yapısal uzaklık) değerinden daha yakın mesafelerle ayrılan örnek noktalarında ilgili 


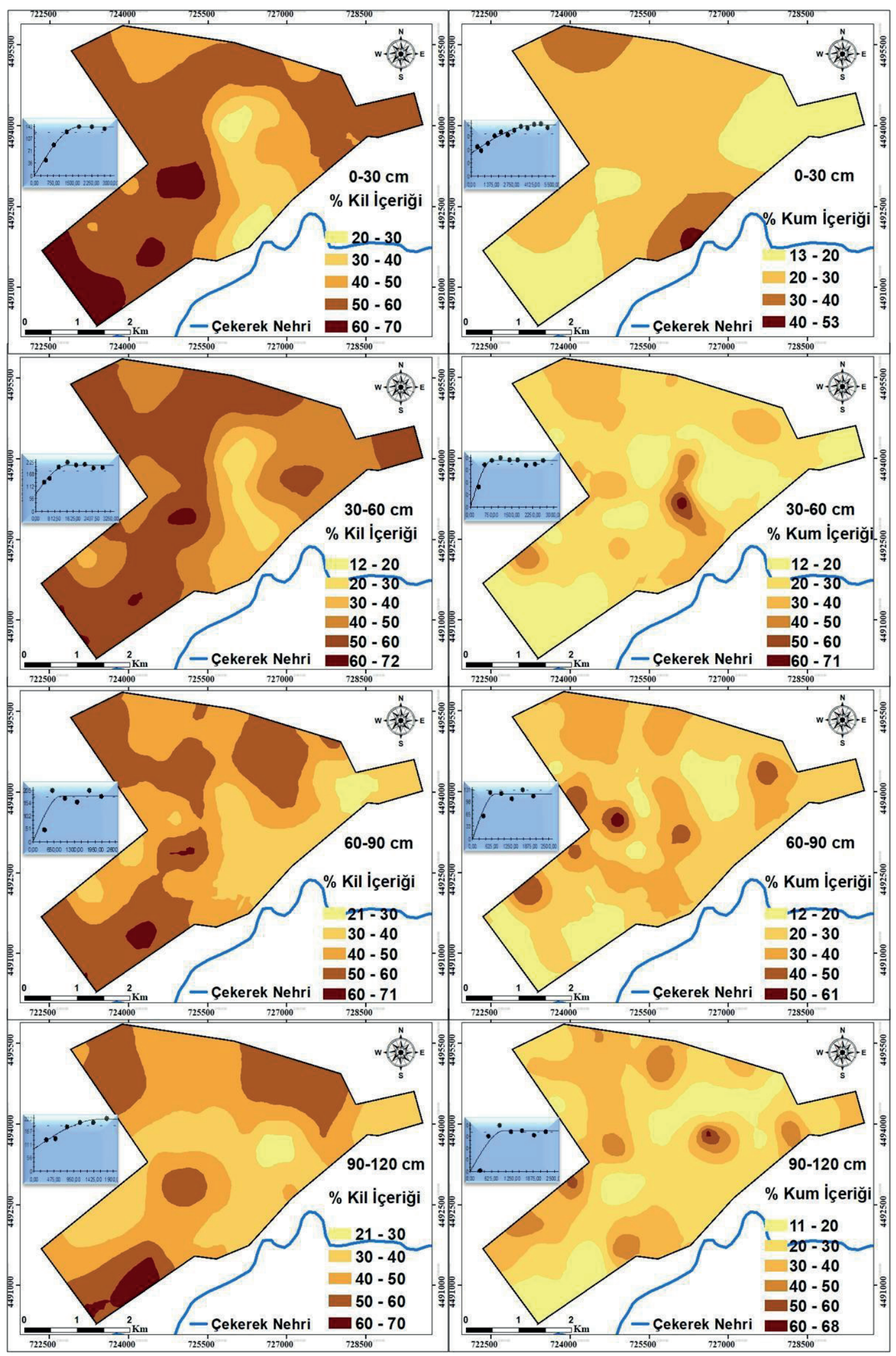

Şekil 2. Çalışma alanı içerisinde kum ve kil içeriklerin dağılımları 


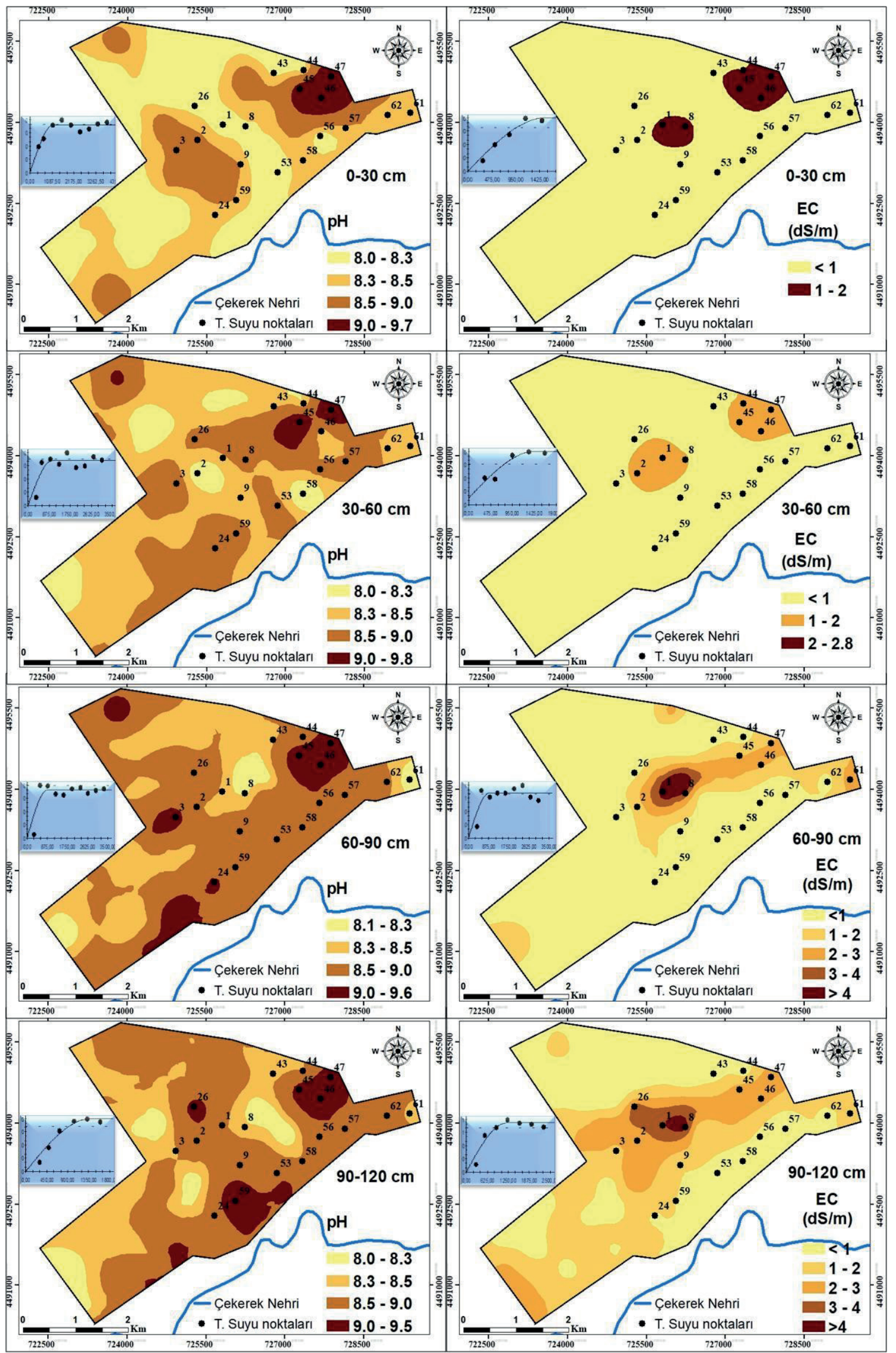

Şekil 3. Çalışma alanı içerisinde $\mathrm{pH}$ ve EC değerlerinin dağılımları 


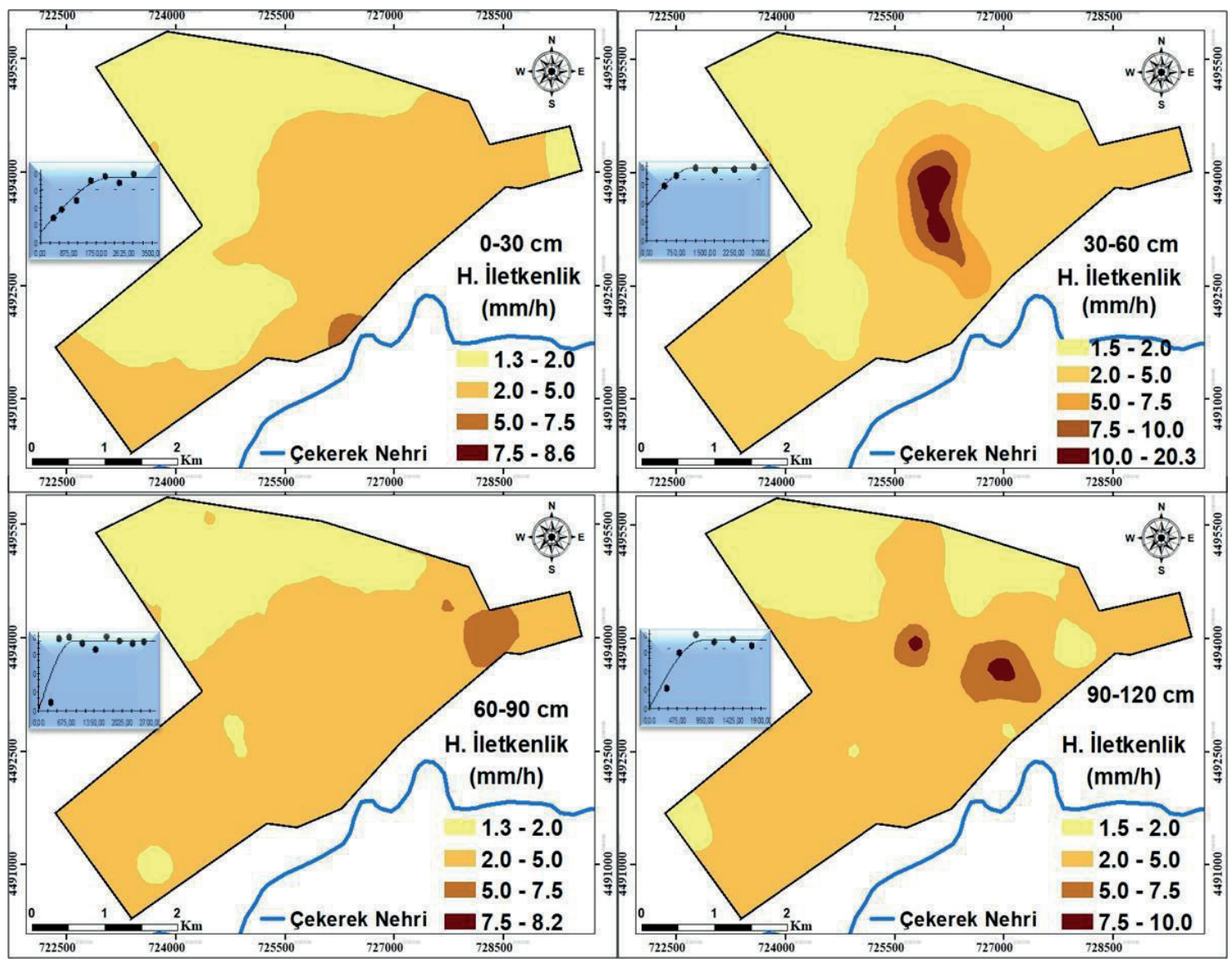

Şekil 4. Çalışma alanı içerisinde hidrolik iletkenlik değerlerinin dağılımları

toprak özelliğinin iki nokta değerleri arasında bir otokorelasyon olduğu ve birbirlerine benzedikleri anlaşılır (Ettema ve Wardle, 2002). Kil içeriği için range değerleri $893 \mathrm{~m}(60-90 \mathrm{~cm})$ ile $1737 \mathrm{~m}(0-30$ $\mathrm{cm})$ arasında değiş̧irken kum içeriği için $751 \mathrm{~m}(60-$ $90 \mathrm{~cm})$ ile $4300 \mathrm{~m}(0-30 \mathrm{~cm})$ arasında değişim göstermiştir (Tablo 3 ). Toprak yüzeyinden derinlere inildikçe hem kil içeriği hem de kum içeriği için toprak örnekleri arasındaki benzerlik daha kısa mesafelerde gözlemlenmiştir. Genetik bir özellik olduğundan dolayı kil ve kum içeriğinin daha uzun mesafelerde değişim göstermesi beklenirken, kısa mesafelerde yüksek yersel değişim göstermesi, Çekerek Nehri tarafından farklı zamanlarda taşınan malzemelerin alanda depolanmış olmasından kaynaklandığı varsayılmaktadır.

Kil ve kum içeriğine ait değişim haritaları Şekil 2'de verilmiştir. Çalışma alanında GüneyDoğu'dan Kuzey-Batı'ya doğru gidildikçe kil içeriği artış göstermiştir. Çalışma alanı iki farklı ana materyal üzerinde oluşmuştur. Çekerek Nehri'ne yakın araziler (Güney-Doğu hattı) aluviyal özellikli iken, alanın Kuzey-Batı hattı ise koluviyal özellikteki arazilerden oluşmaktadır (Sağlam ve ark., 2011). Özellikle koluviyal ana materyal üzerinde oluşan arazilerin kil içeriği yüksek iken, Çekerek Nehri kenarında bulunan aluviyal arazilerin kum içeriği diğer kısımlara göre daha yüksek çıkmıştır. Çalışma alanında hem kil içeriği hem de kum içeriği için elde edilen veriler her dört toprak derinliğinde toprak tekstürünün oldukça yüksek bir değişkenliğe sahip olduğunu göstermektedir. Iqbal ve ark. (2005) akarsular tarafından taşınan alüvyonlar üzerinde oluşan tarım arazilerinde toprak tekstürünün heterojen bir yapıya sahip olduğunu ve çok kısa mesafelerde değişim gösterdiğini bildirmiştir. Arazide toprak tekstüründeki mesafeye bağlı değişim su tutma kapasitesine, suyun yarayışlılığına, suyun hareketine dolayısı ile tuzların yıkanmasına önemli düzeyde etki etmektedir. $\mathrm{Bu}$ nedenle 1slah çalışmalarında hazırlanan değişim haritalarının dikkate alınması gerekmektedir.

\subsubsection{Toprak pH'sı ve elektriksel iletkenliğin derinlikle ve mesafeye bağlı değişimi}

Elektriksel iletkenliğin mesafeye bağlı değişkenliğini gösteren haritalar incelendiğinde arazide ilk $60 \mathrm{~cm}$ derinlikte bitkisel üretime engel olacak düzeyde tuzluluk sorunu olmadiğ 1 anlaşılmaktadır. Bununla birlikte, $60 \mathrm{~cm}$ derinliğin altında EC değerleri özellikle arazinin orta kısmında $2 \mathrm{dS} \mathrm{m}^{-1}$ 'nin üzerine çıktığ 1 görülmektedir (Şekil 3). Örneklemenin çalışma alanında yağışların 
en yoğun olduğu kış ve ilkbahar ayları sonrasında yapıldığı göz önüne alındığında yer yer $4 \mathrm{dS} \mathrm{m}^{-1}$ ye ulaşan hatta bu değeri aşan EC değerlerinin olduğu arazilerde kurak dönemlerde tuzların toprak yüzeyine taşınma riski olduğu unutulmamalıdır. Daha kurak bir dönemde yapılacak olan toprak örneklemelerinde EC değerlerinin üst katmanlarda da daha yüksek olması beklenebilir. Tuzluluk gibi özelliklerin zaman içerisinde değişme potansiyeli farklı dönemde yapılacak örneklemelerde, bu çalışmada elde edilen haritalardan daha farklı mesafeye bağl1 değişkenlik haritalarının elde edilmesine de yol açabilecektir. Ancak, bu bölgede yer alan taban sularının EC değerlerinin de çok yüksek olması, çalışma alanının orta kesimlerinde tuzluluk ile ilgili ıslah çalışmalarının gerekli olduğunu göstermektedir.

Toprakta tuz birikimi fiziksel, kimyasal ve biyolojik işlemleri etkiler (Karlen ve ark., 2008), tarımsal üretimi sınırlandırır ve sürdürülebilirliği tehdit eder (Ellias ve ark., 2013). Toprağın EC değerleri, 60-120 cm derinlikte çalışma alanının orta kismindan Kuzey-Batı ve Güney-Doğu yönlerine doğru uzaklaştıkça giderek azalan bölgesel bir dağılım sergilemektedir (Şekil 3). Arazinin önemli bir kısmında toprak profilinin tamamında EC değerleri sorun olmaktan uzak aralıktadır. $\mathrm{Bu}$ nedenle, çalışma alanı içerisinde gerçekleştirilecek ıslah çalışmalarının 60-120 cm derinlikte EC değerlerinin yüksek olduğu orta kısımdaki arazilerde yoğunlașması hem etkinlik hem de maliyet açısından önemli bir avantaj sağlayacaktır.

Semivariogram sonucu elde edilen verilere göre pH değerleri ve varyasyon katsayısı değerlerine göre arazide büyük değişkenlik gösteriyor olmasına rağmen EC değerleri kuvvetli uzaysal bağımlılığa sahiptir. Uzaysal bağımlılı̆̆ın mesafesini gösteren range değerleri ise $\mathrm{pH} 1156 \mathrm{~m}(0-30 \mathrm{~cm})$ ile $889 \mathrm{~m}$ $(60-90 \mathrm{~cm})$ arasında, EC için $908 \mathrm{~m}(60-90 \mathrm{~cm})$ ile

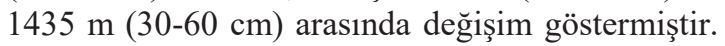
Kurak ve yarı kurak iklim bölgelerinde heterojen bir yap1 gösteren $\mathrm{EC}$ ve $\mathrm{pH}$ değerlerinin uzaysal bağımlılığına toprak tekstürü, değişebilir katyonların cinsi, yıllık yağış miktarı, topografya ve drenaj sistemi önemli derecede etki etmektedir. Bu nedenle her iki özellik için kısa mesafelerde range değerleri elde edilmiştir (Emadi ve ark., 2008).

Toprak pH'sının çalışma alanı içerisindeki dağılım haritaları, EC haritaları ile kısmen benzerlik göstermektedir. En yüksek EC değerlerinin bulunduğu alanlarda hemen her derinlikte pH'nın da çalışma alanı içindeki en yüksek değerleri olduğu görülmektedir. Çalışma alanının KuzeyDoğu'sunda yer alan özellikle $60 \mathrm{~cm}$ derinliğin altındaki katmanlarda tuzluluk sorunlarının görüldüğü arazide pH değerlerinin de yüzeyden itibaren 9.0'ın üzerinde olduğu anlaşıllmaktadır. Ancak EC değerlerinin bitkisel üretim için sorun teşkil etmediği arazinin önemli bir kısmında her dört derinlikte de $\mathrm{pH}$ değerlerinin bitkisel üretim için eşik değer olan 8.5'in üzerine çıktığı tespit edilmiştir (Şekil 3). Toprak pH's1 besin elementlerinin yarayışl1lıklarını etkileyen en önemli kimyasal toprak özelliğidir. Bu nedenle uygulanan gübrelerinin etkinlikleri de toprağın $\mathrm{pH}$ 's1 ile yakından ilişkilidir. Oluşturulan $\mathrm{pH}$ haritalarının kullanımı ile işletme arazilerinin $\mathrm{pH}$ açısından amenajman bölgelerine ayrılması mümkün olabilir. Ayrıca bu alanlarda pH'nın düşürülmesi için düşünülecek kükürtlü sslah maddelerinin kullanımında da bu haritalar önem arz edecektir.

\subsubsection{Hidrolik iletkenliğin derinlik ve mesafeye bağlı değişkenliği}

Toprağın hidrolik iletkenliği, toprakta suyun hareketini ve çözünen maddelerin taşınmasını düzenleyen temel faktör olup (Shwetha ve Varija, 2015); genel olarak toprak yapısına, tekstürüne, organik madde içeriğine ve kütle yoğunluğuna bağl1 olarak değişkenlik göstermektedir (Hillel, 1998). $\mathrm{Bu}$ nedenle, toprak profili boyunca toprağın hidrolojik davranışını belirlemek ıslah çalışmaları için bir ön koşuldur (Huang ve ark., 2016). Özellikle kil içeriği yüksek tuzlu/alkali topraklarda toprak çözeltisinde artış gösteren $\mathrm{Na}$ iyonları, agreagatların parçalanmasına ve toprak kolloidlerinin dispers olmasina neden olduğundan gözenekler tıkanmakta, dolayısı ile topraktaki suyun hareketi önemli derecede yavaşlamaktadır (Horneck ve ark., 2007; Candemir ve Gülser, 2012). Araştırma alanı topraklarının hidrolik iletkenliklerinin mesafeye bağlı değişim desenlerini gösteren haritalar Şekil 4'te, bu haritaları hazırlamak için kullanılan semivariogram modellerine ait parametreler ise Tablo 5'te verilmiştir. Hidrolik iletkenlik için yapılan mesafeye bağlı değişim modelleri incelendiğinde 30-60 cm toprak derinliği için üssel model en iyi model iken, diğer üç derinlik için en iyi model küresel modeldir. İki nokta arasındaki toprak özelliklerinin yersel değişimlerinin boyutunun ifade edilmesinde kullanılan uzaysal bağımlılık değerlerine göre hidrolik iletkenlik her dört derinlikte de kuvvetli derecede bir uzaysal bağımlılık (<\% 25) göstermiştir (Tablo 5). Iversen ve ark. (2003) ve Gupta ve ark. (2006) da jeoistatistiksel analizlerde hidrolik iletkenlik için orta veya kuvvetli uzaysal bağımlılık rapor etmişlerdir.

Oluşturulan semivariogram modellerinde hidrolik iletkenlik için range değerleri 993 m (60$90 \mathrm{~cm})$ ile $1906 \mathrm{~m}(0-30 \mathrm{~cm})$ arasında değişim 
göstermiştir. Hidrolik iletkenlik için derinlikle beraber range değerlerinin önemli düzeyde azalış göstermesi toprak tekstüründe görülen değişimden kaynaklanmaktadır. Aluviyal bir arazide tarla ölçeğinde toprakların hidrolik iletkenliklerine ait uzaysal otokorelayonu değerlendiren Iqbal ve ark. (2005), arazide hidrolik iletkenliğin uzaysal yapısını belirlemek için 100 m'lik örnek aralığının yeterli olacağını bildirmişlerdir. Gwenzi ve ark. (2011), yüzey topraklarında hidrolik iletkenliğe ait uzaysal yapıyı belirlerken range değerini 8 m olarak bulmuşlardır. Hidrolik iletkenliğe ait elde edilen range değerlerinin bu denli farklı olmasının temel nedeni ise, çalışılan toprakların homojenlik düzeylerinin farklılığıdır. Arazi içinde hidrolik iletkenliğin ne olacağı üzerine önemli düzeyde etki eden tekstür, strüktür ve organik madde gibi özelliklerin arazi içerisindeki değişkenliklerinin boyutu range değerinin de kısa veya uzun olmasına etki yapmaktadır. Huang ve ark. (2016) çalıştıkları alanın homojen olmasının hidrolik iletkenlik için range değerinin daha uzun olmasına neden olduğunu bildirmişlerdir.

Hidrolik iletkenlik için hazırlanan değişim haritaları ve elde edilen veriler çalışma alanının neredeyse tamamında toprakta suyun hareketinin oldukça sınırlı olduğuna işaret etmektedir. Ancak çalışma alanının kuzey kısmında suyun hareketinin diğer alanlara göre her dört derinlikte de daha yavaş olduğu görülebilmektedir. Tekstür bileşenleri ile hidrolik iletkenlik değerlerine ait dağılım haritaları karşılaştırıldığında, çalışma alanında arazinin güneyinden geçen Çekerek Nehrine yakın kısımlarda kum içeriğinin yüksek olduğu alanlarda hidrolik iletkenliğin diğer alanlara göre nispeten daha yüksek olduğu anlaşılmaktadır. Çalışma alanında her dört toprak derinliğinde hidrolik iletkenlik değerleri oldukça düşüktür. Bunun temel nedenleri çalışma alanı topraklarının yüksek kil içeriğine (ortalama \% 44.5, 90-120 cm ve \% 50.8, 0-30 cm) sahip olması ve arazinin büyük çoğunluğunun sodik özellikte olmasından kaynaklanmaktadır. Shainberg ve ark. (1981), hidrolik iletkenliğin toprakların değişebilir $\mathrm{Na}$ seviyesine ve toprak çözeltisinin tuz konsantrasyonuna karşı oldukça hassas olduğunu bildirmiştir. Candemir ve Ülser (2012) ise tuzlu alkali topraklarda yaptığı çalışmada, yüksek değişebilir $\mathrm{Na}$ ve düşük miktarda elektrolit konsantrasyonunun agregatların dispers olmasına neden olduğunu ve toprağın geçirgenliğini azalttığını bildirmiştir.

Islah çalışması yapılırken tuzların toprak profilinden hızlı ve etkin bir şekilde uzaklaştırılması için toprakta suyun hareketini kısıtlayan faktörlerin ortadan kaldırılması gerekir. Genellikle sodik topraklarda sodyumun olumsuz etkisini kaldırmak için toprağın kireç içeriğine bağlı olarak farklı katkı maddeleri kullanılmaktadır (Mau ve Porporato, 2016). Ancak arazinin homojen olduğu varsayımı nedeni ile tüm alanda aynı miktarda katkı maddesinin ilavesi oldukça yüksek maliyete neden olabilmektedir. $\mathrm{Bu}$ nedenle daha düşük bir maliyetle etkin bir 1slah çalışması yürütmek için hidrolik iletkenliğe ait spatial değişim haritasının göz önünde bulundurulması kullanıcılara önemli bir avantaj sağlayacaktır.

\section{Sonuçlar}

Bu çalışmada, Gökhöyük Tarım İşletmesi arazilerinde, toprak özelliklerinin dört farklı derinlikteki mesafeye bağlı değişkenlikleri belirlenmiş ve haritalanmıştır. Çalışma alanında yağışın az, buharlaşmanın ise fazla olmasının yanı sıra drenajın yetersiz oluşu alanın bazı kısımlarında $\mathrm{EC}$ ve $\mathrm{pH}$ değerlerinin bitkisel üretimi sınırlandıracak düzeylere çıkmasına neden olduğu ve sorunun derinlikle beraber önemli bir artış gösterdiği tespit edilmiştir. Bitkisel üretim için sorun teşkil edecek bu arazilerin iyileştirilmesinde işletme arazinin tamamının homojen olarak kabul edilmesi, yapılacak iyileştirme faaliyetlerinin çoğunlukla yüksek maliyetli olmasına veya istenilen başarının elde edilememesine neden olacaktır. Bu nedenle bu arazilerde yürütülecek iyileştirme/1slah çalışmalarında yüzey ve yüzey altı toprakların sergilediği mesafeye bağlı değişim deseninin yer aldığı toprak haritalarının göz önünde bulundurulması ve buna uygun işlemlerin yapılması gerekmektedir. Sınırlı sayıdaki toprak özelliği için üretilen mesafeye bağlı değișim haritaları, amaca uygun bir şekilde farklı toprak özellikleri için de üretilip işletme arazisinin sürdürülebilir kullanımına ve toprak kalitesinin geliştirilmesine katk1 sağlanabilir.

\section{Kaynaklar}

Anonymous, 1999. Soil Survey Staff. Soil Taxonomy, a Basic System of Soil Classification for Making and Interpreting Soil Surveys, 2nd Ed.: United States Department of Agriculture, Natural Resources Conservation Service, Agriculture Handbook Number 436, Washington, pp. 870.

Blaylock, A.D., 1994. Soil Salinity, Salt Tolerance, and Growth Potential of Horticultural and Landscape Plants. University of Wyoming, Cooperative Extension Service, Department of Plant, Soil, and Insect Sciences, College of Agriculture. B 988: 1-4.

Bloem, E., Van Der Zee, S.E.A.T.M., Toth, T., Hagyó, A., 2007. Risk Assessment Methods of Salinity. JCRIES. Sixth Framework Programme, Scientific Support to Policies Project Report 2.4, pp. 6-13.

Budak, M., Günal, H., 2015. Tuzlu-alkali topraklarda bor konsantrasyonunun uzaysal değişkenliğinin jeoistatistiksel analizi ve haritalanması. Ege 
Üniversitesi Ziraat Fakültesi Dergisi, 52(2): 191200.

Cambardella, C.A., Moorman, T.B., Parkin, T.B., Karlen, D.L., Novak, J.M., Turco, R.F., Konopka, A.E., 1994. Field-scale variability of soil properties in central Iowa soils. Soil Science Society of America Journal, 58(5): 1501-1511.

Candemir, F., Gülser, C., 2012. Influencing factors and prediction of hydraulic conductivity in fine-textured alkaline soils. Arid Land Research and Management, 26(1): 15-31.

Corwin, D.L., Rhoades, J.D., Šimůnek, J., 2007. Leaching requirement for soil salinity control: Steady-state versus transient models. Agricultural Water Management, 90(3): 165-180.

Dengiz, O., Özyazıcı, M.A., Sağlam, M., 2015. Multicriteria assessment and geostatistical approach for determination of rice growing suitability sites in Gokirmak catchment. Paddy and Water Environment, 13(1): 1-10.

Eckelmann, W.R., Baritz, S., Bialousz, P., Bielek, F., Carre, B., Houšková, R.J.A., Jones, M.G., Kibblewhite, J., Kozak, C., Le Bas, G., Tóth, T., Tóth, G., Várallyay, M., Yli Halla, M., Zupan, M., 2006. Common Criteria for Risk Area Identification According to Soil Threats. European Soil Bureau Research Report No.20, EUR 22185 EN, Office for Official Publications of the European Communities, Luxembourg.

Eliáš, P., Dítě, D., Šuvada, R., Píš, V., Ikrényi, I., 2013. Hordeum geniculatum in the Pannonian Basin: Ecological requirements and grassland vegetation on salt-affected soils. Plant Biosystems-An International Journal Dealing with all Aspects of Plant Biology, 147(2): 429-444.

Emadi, M., Baghernejad, M., Maftoun, M., 2008. Assessment of some soil properties by spatial variability in saline and sodic affected soils in Arsanjan Plain, Fars Province, Southern Iran. Pakistan Journal of Biological Sciences, 11(2): 238243.

Ettema, C.H., Wardle, D.A., 2002. Spatial soil ecology. Trends in Ecology \& Evolution, 17(4): 177-183.

Gao, X., Niu, C., Chen, Y., Yin, X., 2014. Spatial heterogeneity of stream environmental conditions and macroinvertebrates community in an agriculture dominated watershed and management implications for a large river (the Liao River, China) basin. Environmental Monitoring and Assessment, 186(4): 2375-2391.

Gee, G.W., Bauder, J.W., 1986. Particle-Size Analysis. Methods of Soil Analysis: Part 1 Physical and Mineralogical Methods, (Methodsofsoilan1), Soil Science Society of America, American Society of Agronomy, pp.383-411.

Goovaerts, P., 1999. Geostatistics in soil science: State of the art and perspectives. Geoderma, 89(12): 1-45.

Gupta, N., Rudra, R.P., Parkin, G., 2006. Analysis of spatial variability of hydraulic conductivity at field scale. Canadian Biosystems Engineering, 48(1): 5562.
Günal, H., Acir, N., Polat, A., Günal, E., Budak, M., Erdem, N., Mal1, Z., Önen, H., 2015. Tuzlu ve bor toksikliği bulunan arazilerin idaresinde mesafeye bağlı değişkenliğin önemi. Anadolu Tarım Bilimleri Dergisi. 30: 189-198.

Gwenzi, W., Hinz, C., Holmes, K., Phillips, I.R., Mullins, I.J., 2011. Field-scale spatial variability of saturated hydraulic conductivity on a recently constructed artificial ecosystem. Geoderma, 166(1): 43-56.

Hillel, D., 1998. Environmental Soil physics: Fundamentals, Applications, and Environmental Considerations. Elsevier, Academic Press, New York, United States of America, pp. 771.

Horneck, D.A., Ellsworth, J.W., Hopkins, B.G., Sullivan, D.M., Stevens, R.G., 2007. Managing Salt-Affected Soils for Crop Production. A Pacific Northwest Extension, Oragen State University, pp.1-24.

Horney, R.D., Taylor, B., Munk, D.S., Roberts, B.A., Lesch, S.M., Plant, R.E., 2005. Development of practical site-specific management methods for reclaiming salt-affected soil. Computers and Electronics in Agriculture, 46: 379-397.

Huang, M., Zettl, J.D., Barbour, S.L., Pratt, D., 2016. Characterizing the spatial variability of the hydraulic conductivity of reclamation soils using air permeability. Geoderma, 262: 285-293.

Iqbal, J., Thomasson, J.A., Jenkins, J.N., Owens, P.R., Whisler, F.D., 2005. Spatial variability analysis of soil physical properties of alluvial soils. Soil Science Society of America Journal, 69(4): 1338-1350.

Iversen, B.V., Moldrup, P., Schjonning, P., Jacobsen, O.H., 2003. Field application of a portable air permeameter to characterize spatial variability in air and water permeability. Vadose Zone Journal, 2(4): 618-626.

Kalivas, D.P., Triantakonstantis, D.P., Kollias, V.J., 2002. Spatial prediction of two soil properties using topographic information. Global Nest: The International Journal, 4(1): 41-49.

Karaca, S., 2008. Amasya-Doğantepe Beldesi ve yakın çevresinin kırsal arazi değerlendirmesi. Doktora Tezi, Ankara Üniversitesi Fen Bilimleri Enstitüsü, Ankara.

Karlen, D.L., Tomer, M.D., Neppel, J., Cambardella, A., 2008. A preliminary watershed scale soil quality assessment in north central Iowa. Soil and Tillage Research, 99: 291-299.

Mau, Y., Porporato, A., 2016. Optimal control solutions to sodic soil reclamation. Advances in Water Resources, 91: 37-45.

Mulla, D.J., McBratney, A.B., 2000. Soil spatial variability. ME Sumner (Ed.), Handbook of Soil Science, CRC Press, Boca Raton, FL. pp. A321A352.

Özyazıcı, M.A., Dengiz, O., Aydoğan, M., Bayraklı, B., Kesim, E., Urla, Ö., Yıldı, H., Ünal, E., 2015. Orta ve Doğu Karadeniz Bölgesi tarım topraklarının bazı makro ve mikro bitki besin maddesi konsantrasyonları ve ters mesafe ağırlık yöntemi (IDW) ile haritalanmas1. Artvin Çoruh Üniversitesi Orman Fakültesi Dergisi, 16(2): 187-202. 
Özyazıcı, M.A., Dengiz, O., Aydoğan, M., Bayraklı, B., Kesim, E., Urla, Ö., Yıldız, H., Ünal, E., 2016. Orta ve Doğu Karadeniz Bölgesi tarım topraklarının temel verimlilik düzeyleri ve alansal dağılımları. Anadolu Tarım Bilimleri Dergisi, 31(1): 136-148.

Özyazıcı, M.A., Dengiz, O., Özyazıcı, G., 2017. Spatial distribution of heavy metals density in cultivated soils of Central and East Parts of Black Sea Region in Turkey. Eurasian Journal of Soil Science, 6(3): 197205.

Rhoades, J.D., Chanduvi, F., 1999. Soil salinity assessment: Methods and interpretation of electrical conductivity measurements. Food and Agriculture Orginization of the United Nations, 57, pp: 5-15.

Richards, L.A., Allison, L.E., Bernstein, L., Bower C.A., Brown, J.W., Fireman, M., Hatcher, J.T., Hayward, H.E., Pearson, G.E., Reeve, R.C., Wilcox, L.V., 1954. United States Salinity Laboratory Staff. Diagnosis and Improvement of Saline and Alkali Soils. United States Department of Agriculture, Agriculture Handbook No: 60, United States Government Printing Office, Washington, pp. 160.

Russo, D., 1984. Spatial Variability Considerations in Salinity Management. In: I. Shainberg and J. Shalhvet (Ed.), Soil Salinity Under Irrigation, Springer Berlin, pp. 198-216.

Sağlam, M., Öztürk, H.S., Erşahin, S., Özkan, A.İ., 2011. Spatial variation of soil physical properties in adjacent alluvial and colluvial soils under Ustic moisture regime. Hydrology and Earth System Sciences Discussions, 8(2): 4261-4280.

Samra, J.S., Singh, V.P., 1990. Spatial dependence of soil reclamation. Soil Technology, 3(2): 153-165.
Saxton, K.E., Rawls, W., Romberger, J.S., Papendick, R.I., 1986. Estimating generalized soil-water characteristics from texture. Soil Science Society of America Journal, 50(4): 1031-1036.

Shainberg, I., Rhoades, J.D., Prather, R.J., 1981. Effect of low electrolyte concentration on clay dispersion and hydraulic conductivity of a sodic soil. Soil Science Society of America Journal, 45(2): 273-277.

Shwetha, P., Varija, K., 2015. Soil water retention curve from saturated hydraulic conductivity for sandy loam and loamy sand textured soils. Aquatic Procedia, 4: 1142-1149.

Sürücü, A., Günal, H., Acir, N., 2013. Importance of spatial distribution in reclamation of boron toxic soils from Central Anatolia of Turkey. Fresenius Environmental Bullettin, 22(11): 3111-3122.

Triantafilis, J., Lesch, S.M., 2005. Mapping clay content variation using electromagnetic induction techniques. Computers and Electronics in Agriculture, 46: 203237.

Webster, R., Oliver, M.A., 2001. Geostatistics for Environmenntal Scientists. Statistics in Practice. John Wiley, England, pp. 265.

Wilding, L.G., 1985. Spatial Variability: Its Documentation, Accommodation and Implication to Soil Surveys. In: D.R. Nielsen and J. Bouma (Eds), Soil Spatial Variability, Pudoc, Wageningen, pp. 166193.

Yang, F., Zhang, G., Yin, X., Liu, Z., 2011. Field-scale spatial variation of saline-sodic soil and its relation with environmental factors in Western Songnen Plain of China. International Journal of Environmental Research and Public Health, 8(2): 374-387. 